\title{
Cultural proximity: a source of trade flow resilience?
}

\author{
Céline CArrère, Maria Masood
}

\author{
C CÉline Carrère, University of Geneva, CEPR and FERDI \\ E-mail: celine.carrere@unige.ch
}

C Maria Masood, University of Geneva |E-mail: Maria.Masood@unige.ch

\section{Abstract}

While the significant influence of cultural proximity on bilateral trade flows has been extensively documented in the literature, its possible role in times of crisis has not yet been raised. Relying on a panel estimation of a gravity model incorporating cultural proximity parameters, we evidence the existence of a significant surge in the impact of the different components of cultural proximity during economic recession. The trade resilience among countries sharing a cultural bond is not a pure composition effect as it also appears within product categories. To understand this unexpected effect, we discuss different mechanisms that emphasize the potential mitigating influence of cultural proximity on some determinants of the trade collapse, namely the uncertainty shock, the increased moral hazard and the emergence of ethnocentric preferences.

Keywords: Bilateral trade, cultural proximity, financial crisis, trade resilience.

JEL Classification: F10, F14, Z10

\section{Acknowledgements}

The authors are very grateful to Marcelo Olarreaga, Robert Staiger and Farid Toubal for their helpful comments. This paper benefited from the financial support of the FERDI (Fondation pour les Etudes et Recherches sur le Développement International) and of the program "Investissement d'Avenir" (reference ANR-10-LABX-14-01) of the French government.

Maria Masood thanks the Fondation de Famille Sandoz for funding under the "Sandoz Family Foundation - Monique de Meuron" Programme for Academic Promotion. 



\section{Introduction}

Although trade liberalization has reached unprecedented levels, barriers to trade remain high. Sharing common cultural traits plays an important role in reducing informal barriers to bilateral trade (Guiso et al. 2009, Anderson and Van Wincoop, 2004) as evidenced in a growing number of trade analyses ${ }^{1}$. The question is to know how cultural proximity affects trade in the event of crisis. It could reduce trade of partners that share the same culture (through for instance intensified contagion effect) or could dampen the crisis' effects, offering a better resilience of trade flows. This is an empirical question that has not been answered yet. In this paper, we provide an empirical investigation of the effect of cultural proximity on bilateral trade flows in times of economic turbulences for a large sample of countries over 20 years, with a focus on the 2008/2009 financial crisis.

To do so we rely on the estimation of a structural gravity equation as a sound workhorse for estimating the respective influence of the different determinants of bilateral trade that could overlap with cultural proximity. Our analysis is based on the gravity model developed by Felbermayr \& Toubal (2010) that explicitly takes into account cultural proximity specificities. We face then two main challenges: first, the concept of cultural proximity is very broad and multidimensional and, second, we need to identify economic crisis experiences. Regarding the first point, the growing literature helps a lot. Different measures of cultural proximity have been used: (i) traditional gravity variables such as the sharing of a common language (Egger \& Weber 2016, Carrère \& Masood 2015, Melitz \& Toubal 2014, Egger \& Lassmann 2012, Melitz 2008) or colonial ties (Head et al. 2010); (ii) variables proxying bilateral trust and values (Ahern et al. 2015, Maystre et al. 2014); or (iii) through innovative indicators of similar tastes, such as Felbermayr \& Toubal (2010) who construct their measures based on an international song contest. In this paper, we base our analysis on the first set of measures of cultural proximity that is available for a large sample, namely common language, a common colonial history, a same origin of the legal system and a religious proximity. Regarding the second point, we follow Braun and Larrain (2005) and identify recessions relying on the fluctuations of total GDP (in annual frequency). A recession ${ }^{2}$ occurs in a country when cyclical GDP (defined as the difference between the actual GDP and its long-term trend) is more than one standard deviation below zero, the standard deviation being computed for each country.

The estimation of our structural gravity model using the Pseudo Poisson Maximum Likelihood (PPML) estimator on a sample of 140 countries over the 1995-2015 period, evidence the existence of a significant surge in different dimensions of cultural proximity (namely, common language, common colonial history, a same origin of the legal system and religious proximity) during an economic recession. Sharing a common colonial past is associated with higher bilateral trade flows

\footnotetext{
${ }^{1}$ For a summary of this corpus, the reader can refer to the meta-analyses done by Head \& Mayer (2014) and Egger \& Lassmann (2012).

2 The terms "crisis" and "recession" are used interchangeably in the text.
} 
by $17 \%$ during crisis compared to already favored "normal" (i.e. non crisis) period, all other things being equal. In the same way, sharing a common legal system provides a better resilience by around $15 \%$, a common language by $11 \%$ and a common religion by $9.5 \%$. If the large correlation existing among these variables prevents us from ranking the different cultural components, it is obvious that sharing some of these characteristics matters in recession time on trade flows.

What are the reasons for this higher trade impact of cultural proximity variables during crises? This result is not intuitive as the collapse in import demand and/or export supply is controlled for by the year-importer and year-exporter fixed effects in our estimations. A potential explanation is the aggregation bias. Given that, in "normal" time, cultural proximity has a stronger effect on trade in differentiated products (according to the Rauch classification), an increasing share of these products in total trade during an economic crisis would mechanically inflate the coefficient for cultural proximity. While we cannot find evidence of a significant change in trade composition during economic crisis, we also observe that cultural proximity increases resilience within the differentiated products category. Several economic mechanisms that can explain the surge in the effect of cultural proximity on trade are then discussed. In particular, we investigate the mitigating effect that cultural proximity can play on some determinants of the disproportionate decline in international trade (compared to the decrease in output) in recent crisis, such as the uncertainty shock, the increased moral hazard and the emergence of ethnocentric preferences.

The paper is structured as follows: Section 2 develops the gravity model incorporating bilateral cultural proximity parameters. Empirical results about the dynamic effect of cultural proximity during crisis period are reported in Section 3. Section 4 explores possible explanations of the better resilience of trade between culturally proximate countries during a recession, with a focus on the 2008/2009 financial crisis. Section 5 concludes.

\section{Cultural proximity in the Gravity equation}

Starting from the general gravity equation as defined by Head \& Mayer (2014), imports of country $i$ from country $j$ in year $t$ can be expressed as:

$$
M_{i j t}=D_{i t} S_{j t} \phi_{i j t}
$$

With $D_{i t}$ capturing all characteristics of the importer market $i$ in $t$ that promote imports from all sources, $\mathrm{S}_{\mathrm{jt}}$ being the "capabilities" of exporter $j$ in $t$ as a supplier to all destinations and $\phi_{i j t}$ representing the dyadic accessibility of exporter $j$ to $i$ in $t$.

\subsection{Trade in a standard monopolistic competition setting}

More specifically, we use a demand-side model based on standard symmetric Dixit-StiglitzKrugman (DSK) monopolistic competition assumptions. It assumes that (i) each country $j$ has $N_{j}$ firms, each supplying one variety to the world from a home country production site, (ii) Utility 
features a constant elasticity of substitution, denoted $\sigma$, across all varieties available in the world (iii) bilateral trade costs $\tau_{i j t}$ take the iceberg form.

Hence, it follows that

$D_{i t}=Y_{i t} P_{i t}^{1-\sigma}, Y_{i t}$ being the importer's GDP and $P_{i t}$ the importer aggregate price index.

$S_{j t}=N_{j t} p_{j t}^{1-\sigma}$, with $\mathrm{p}_{\mathrm{jt}}$ being f.o.b price.

These two terms will be controlled for by importer-year and exporter-year fixed effects respectively.

More importantly for our purpose is the derivation of the expression of bilateral accessibility of exporter $j$ to importer $i$ in $t$, and the identification of the role of cultural proximity. Recent contributions (Combes et al. 2005, Felbermayr \& Toubal 2010) have formalized the two main channels through which cultural proximity influences bilateral trade flows in the gravity equation, namely: the preference channel and the trade costs channel. Cultural proximity correlates with a higher mutual interest for the goods produced in culturally similar countries, increasing the bilateral taste parameter or lowering the cultural discount. Simultaneously, cultural proximity also lowers trade costs as it facilitates the formation of business and social networks, reduces the need for communication-related consulting services and it increases the level of trust.

Hence, we follow Felbermayr and Toubal (2010) and assume that the influence of cultural proximity on $\phi_{i j t}$ (and then bilateral trade) is twofold: via the preference and via the trade costs channels.

\subsection{Cultural proximity: the preference channel}

The utility of a representative consumer in country $i$ is based on the consumption of different varieties of a differentiated good (in a standard CES function) associated to a specific positive weight, denoted $a_{i j}$, that describes the distinct preferences for goods originating from exporter $j$ in $t$.

Maximizing this utility function subject to a budget constraint and given previous assumptions, we obtain the following expression for bilateral accessibility:

$$
\phi_{i j t}=\left(\frac{a_{i j}}{\tau_{i j t}}\right)^{\sigma-1}
$$

We assume that country i's preferences for goods originating from $j$ depends on Cultural Proximity $\mathrm{CP}_{\mathrm{ij}}$ in the following way:

$$
a_{i j}=C P_{i j}^{\alpha} \text { with } a>0
$$




\subsection{Cultural proximity: the trade costs channel}

We assume a usual trade costs function, i.e. $\tau_{i j t}$, that depends upon (i) transport costs, proxied by geographic distance DIST $T_{i j}$ and the existence of a common border Contig $g_{i j}$ (ii) trade policies, proxied by the existence of a regional trade agreement (RTA) between $i$ and $j$ in $t$, and (iii) what Felbermayr and Toubal termed the "costs of contracting and negotiation" that are clearly dampened by $\mathrm{CP}_{\mathrm{ij}}$. Hence, the following trade costs function can be defined as follows:

$$
\tau_{i j}=C P_{i j}^{-\pi} D I S T_{i j}^{\delta_{1}} e^{-\delta_{2} \operatorname{Contig}_{i j}-\delta_{3} R T A_{i j t}} \text { with } \delta_{x}, \pi>0
$$

Note that determinants of trade costs that are country-specific (such as being landlocked or being an island) are captured by the individual country fixed-effects.

\subsection{Approximation of Cultural proximity}

We rely on the usual time-invariant measures of cultural proximity that are available for a large sample of countries in the gravity literature, namely (and following Felbermayr \& Toubal, 2010 and Head \& Mayer, 2014): common language $\left(C L_{i j}\right)$, common colonial history (Colony $\left.y_{i j}\right)$, common origin of the legal system (Legal $\left.I_{i j}\right)$ and religious proximity (Religion $n_{\mathrm{ij}}$ ). Source and computation of these variables are detailed in the annex $\mathrm{A} 1$.

$$
C P_{i j}=e^{\kappa_{1} C L_{i j}+\kappa_{2} \text { Legal }_{i j}+\kappa_{3} \text { Religion }_{i j}+\kappa_{4} \text { Colony }_{i j}}
$$

\subsection{Empirical gravity equation}

Based on preceding equations and after a log-linearization we obtain:

$$
\begin{aligned}
& \text { lnM }_{i j t}=\bar{\kappa}_{1} \text { CL }_{i j}+\bar{\kappa}_{2} \text { Legal }_{i j}+\bar{\kappa}_{3} \text { Religion }_{i j}+\bar{\kappa}_{4} \text { Colony }_{i j} \\
& \quad-\bar{\delta}_{1} \ln \left(\text { DIST }_{i j}\right)+\bar{\delta}_{2} \text { Contig }_{i j}+\bar{\delta}_{3} R T A_{i j t}+v_{i t}+v_{i t}+\varepsilon_{i j t}
\end{aligned}
$$

With $\bar{\kappa}_{x}=(\sigma-1)(\alpha+\pi) \kappa_{x}, \bar{\delta}_{x}=(\sigma-1) \delta_{x}$

The focus of the empirical investigation is on the vector of parameters $\bar{\kappa}_{x}$ and its evolution over time, and more particularly during recessions. To do so, we estimate equation (6) relying on aggregate bilateral trade flows for a sample of around 140 countries over 1995-2015 (407,320 observations). ${ }^{3}$ We follow Silva \& Tenreyro (2006) and use the pseudo poisson maximum likelihood (PPML) estimator to take into account the large fraction of zero bilateral trade flows ( $23 \%$ of the sample) and heterogeneity issues. For a more detailed presentation of the variables used for the estimation (sources, computation and descriptive statistics), the reader can refer to annex A1.

\footnotetext{
${ }^{3}$ We drop from the sample countries/territories with less than 1 million inhabitants in 2000 which usually report a lot of zero trade flows. We present a robustness check of our main results with the 186 countries.
} 


\section{The trade impact of cultural proximity during an economic crisis}

\subsection{Baseline results: the average impact of cultural proximity on trade flows}

In a first step, we estimate the effect of the cultural proximity variables on bilateral trade flows between 1995 and 2015. The corresponding results are reported in Table 1.

Coefficients reported in Table 1 are in line with the empirical trade literature: increasing distance by $10 \%$ reduces trade flows by around $7 \%$ while countries sharing a common land border or belonging to a same regional trade agreements trade about $43 \%$ and $58 \%$ more respectively, all other things being equal. In addition to geography and trade policies, cultural proximity seems to matter: two countries that can easily communicate thanks to a common language trade about $10.5 \%$ more 4 . A common legal system boosts trade by $19.5 \%$. Sharing a common past colonial history or a same religion slightly increase aggregate trade by $17.4 \%$ and $10.4 \%$ respectively. Note that it is not always easy to precisely disentangle the impact of each component of cultural proximity given the existence of an important collinearity among these variables, especially with the common language dummy (see the correlation matrix in appendix A1, Table A2).

We then go beyond aggregate trade and decompose trade flows into the Rauch (conservative) classification: differentiated goods (col.2), reference priced goods (col.3) and homogeneous goods - i.e. goods traded on an organized exchange (col.4). As reported in equation (6), all coefficients depend on the elasticity of substitution via the term $(\sigma-1)$. The more homogenous the good, the higher the elasticity of substitution. Hence, we expect a higher elasticity to trade costs in case of homogenous goods, which is the case for distance or contiguity. However, except for past colonial history (most likely driven by natural resources trade flows), cultural proximity goes the other way: sharing a common language, religion or legal system is more important for differentiated goods than for homogenous. Indeed, as emphasized by Rauch (1999) trading processes vary greatly according to the type of good that is traded. While homogeneous goods have referenced price quoted either on organized exchange or in trade publications, trade in differentiated products require buyers and sellers to engage in a sequential search. This matching process is facilitated by the existence of cultural ties enabling a better knowledge of the market and influencing the composition of the traders' network. This result is in line with the findings of Guiso et al. (2009), Felbermayr \& Toubal (2010) and Egger \& Toubal (2016). This implies a higher $\pi$, i.e. a higher dampening impact of cultural proximity on trade cost, for differentiated goods. Moreover, one can also expect a higher impact of cultural proximity on differentiated goods trade via the preference channel $(\alpha)$ reinforcing the effect of these variables.

\footnotetext{
${ }^{4}$ Following Melitz \& Toubal (2014), we attempted to decompose the common language variable into common spoken, common native language and common official language. Yet, the results are highly volatile and difficult to interpret, certainly due to the large multicollinearity among the language dummies (with a correlation above $80 \%$ in our sample between common spoken and official language, see table A1 in annex A1) and more generally among the language dummies and the other cultural proxies. This problem was also noted in Melitz \& Toubal (2014).
} 
Table 1: Average impact of cultural proximity over 1995-2015

\begin{tabular}{|c|c|c|c|c|}
\hline Trade flows & $\begin{array}{c}\text { (1) } \\
\text { All but Minerals }\end{array}$ & $\begin{array}{c}(2) \\
\text { Differentiated }\end{array}$ & $\begin{array}{c}\text { (3) } \\
\text { Referenced price }\end{array}$ & $\begin{array}{c}\text { (4) } \\
\text { Homogeneous }\end{array}$ \\
\hline \multicolumn{5}{|c|}{$\begin{array}{l}\text { Cultural Proximity } \\
\text { variables }\end{array}$} \\
\hline \multirow[t]{2}{*}{$\mathrm{CL}_{\mathrm{ij}}$} & $0.100^{*}$ & $0.182^{*}$ & -0.00791 & $0.110^{*}$ \\
\hline & $(0.0524)$ & $(0.108)$ & $(0.0667)$ & $(0.0656)$ \\
\hline \multirow[t]{2}{*}{ Legal $_{i j}$} & $0.178^{* * *}$ & $0.251^{* * *}$ & $0.157^{* * *}$ & $0.117^{*}$ \\
\hline & $(0.0375)$ & $(0.0360)$ & $(0.0415)$ & $(0.0706)$ \\
\hline \multirow[t]{2}{*}{ Religion $_{\mathrm{ij}}$} & $0.0985^{* *}$ & $0.0848^{*}$ & 0.0602 & $-0.359 * * *$ \\
\hline & $(0.0410)$ & $(0.0453)$ & $(0.0492)$ & $(0.0843)$ \\
\hline \multirow[t]{2}{*}{ Colony $_{\mathrm{ij}}$} & $0.160^{*}$ & 0.0170 & $0.326^{* * * *}$ & $0.400 * * *$ \\
\hline & $(0.0829)$ & $(0.0824)$ & $(0.0897)$ & $(0.111)$ \\
\hline \multicolumn{5}{|c|}{ Other trade costs } \\
\hline \multirow[t]{2}{*}{ Dist $_{i j}$} & $-0.709 * * *$ & $-0.677^{* * *}$ & $-0.777^{* * *}$ & $-1.007^{* * *}$ \\
\hline & $(0.0316)$ & $(0.0318)$ & $(0.0353)$ & $(0.0595)$ \\
\hline \multirow[t]{2}{*}{ Contigij $_{i j}$} & $0.356^{* * *}$ & $0.313^{* * *}$ & $0.366^{* * *}$ & $0.395^{* * *}$ \\
\hline & $(0.0585)$ & $(0.0596)$ & $(0.0611)$ & $(0.118)$ \\
\hline \multirow[t]{2}{*}{$\mathrm{RTA}_{\mathrm{ij}}$} & $0.457^{* * *}$ & $0.488^{* * *}$ & $0.588^{* * *}$ & $0.234^{* *}$ \\
\hline & $(0.0532)$ & $(0.0562)$ & $(0.0627)$ & $(0.0949)$ \\
\hline Observations & 407,320 & 407,320 & 407,320 & 407,320 \\
\hline R-squared & 0.908 & 0.941 & 0.875 & 0.698 \\
\hline
\end{tabular}

Note: This table displays the results of the estimation of a structural gravity model with PPML performed on a sample of 140 countries between 1995 and 2015. All regressions include origin*year and destination*year fixed effects and standard errors are clustered at the country-pair level. CL refers to common language; Contig to Contiguity; Dist to Distance and RTA to Regional Trade Agreement.

${ }^{* * *} p<0.01,{ }^{* *} p<0.05,{ }^{*} p<0.1$

\subsection{The effect of cultural proximity during crises}

This section focuses on the evolution of the effect of cultural proximity on trade when a recession occurs. As a preliminary step, we need to define the years of recession for 140 countries, over the 1995-2015 period (and up to 186 countries in the robustness checks). To do so, we follow Braun and Larrain (2005) and identify recessions relying on the fluctuations of total GDP (in annual frequency). We take the cyclical component of GDP defined as the difference between the actual GDP and a trend computed using the Hodrick-Prescott filter. A recession ${ }^{5}$ occurs in a country when cyclical GDP is more than one standard deviation below zero, the standard deviation being computed for each country. A recession goes from the year after the peak - defined as a year just before the trough in which cyclical GDP is higher than in both the previous and the posterior yearsto the year of the trough (see appendix A1 for more details).

\footnotetext{
${ }^{5}$ The terms "crisis" and "recession" are used interchangeably in the text.
} 
We report in Figure 1 the occurrence of the recession dummy per year. The financial crisis in 2009 is clearly identified, as well as the decline in economic activities in the early 2000 s.

Figure 1: Occurrence of the Recession dummy per year, 1995-2015

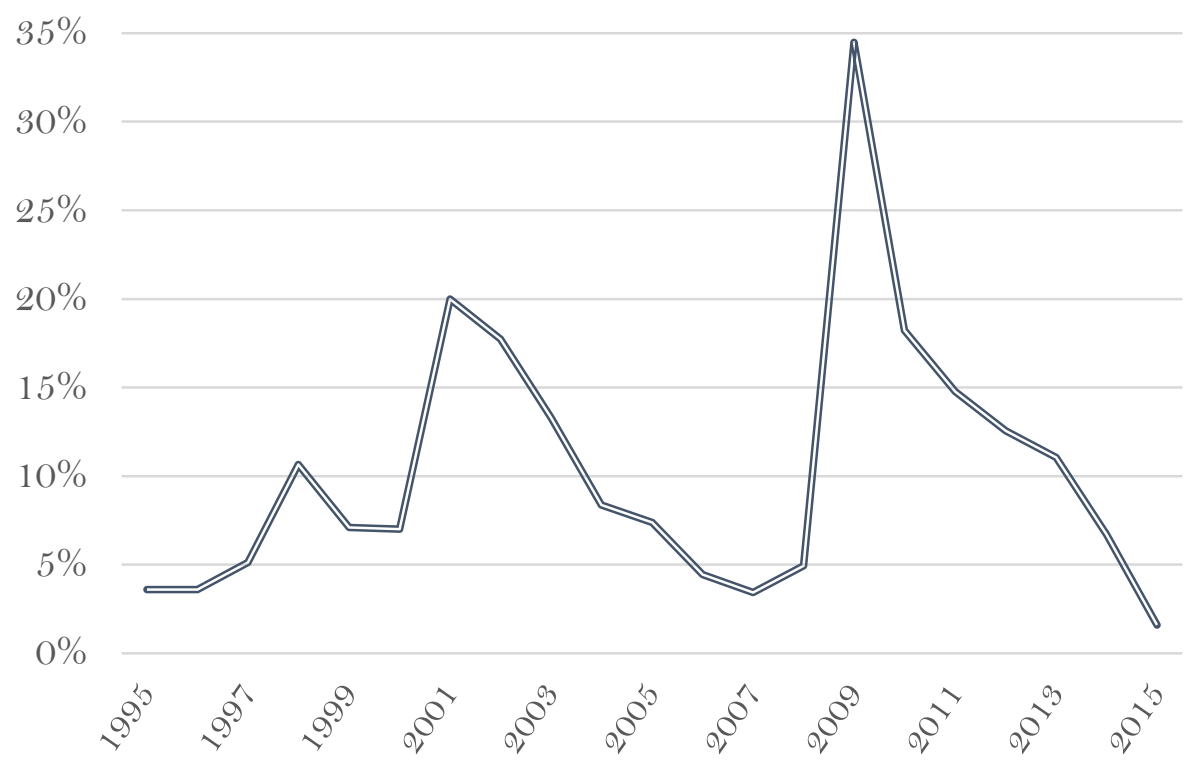

Note: The Recession dummy is computed as a dummy variable equal to one if a country-pair experiences a recession in a given year. A recession year is defined as a year during which the GDP deviates by more than one (negative) standard deviation from its trend level (computed using the Hodrick-Prescott filter).

Based on this measure, we re-estimate equation (6) introducing, for each of the trade costs variable, an interaction term with a time trend ${ }^{6}$ and with the "Recession" dummy that takes the value 1 if both the importer and exporter countries are experiencing a recession in year $t^{7}$ Detailed results for all variables are reported in annex A2 (table A3) and we summarize in Figure 2 the coefficients (with $90 \%$ confidence intervals) obtained for each variable of cultural proximity interacted with the Recession dummy. All these coefficients are positive and significant. Given the drop in trade flows commonly expected during an economic recession, the surge in the cultural proximity coefficients - once controlled for other trade costs and exporter-year/importer-year fixed effects - implies a better resilience (lower drop) in trade flows for the bilateral pairs concerned. In this figure, there is no distinction across types of goods, however in Figure 4, we go further in the estimation and show that the supplemental effect of cultural proximity during the crisis concerns primarily the differentiated product as expected (see the corresponding discussion in Section 4.1)

\footnotetext{
${ }^{6}$ As we know that some cultural component experience a decreasing impact on trade through time in the long-run, see Carrère and Masood (2015) for common language, Head at al. (2010) for colonial links.

${ }^{7}$ We will also test in robustness the effect when only one of the two countries experiences a recession.
} 


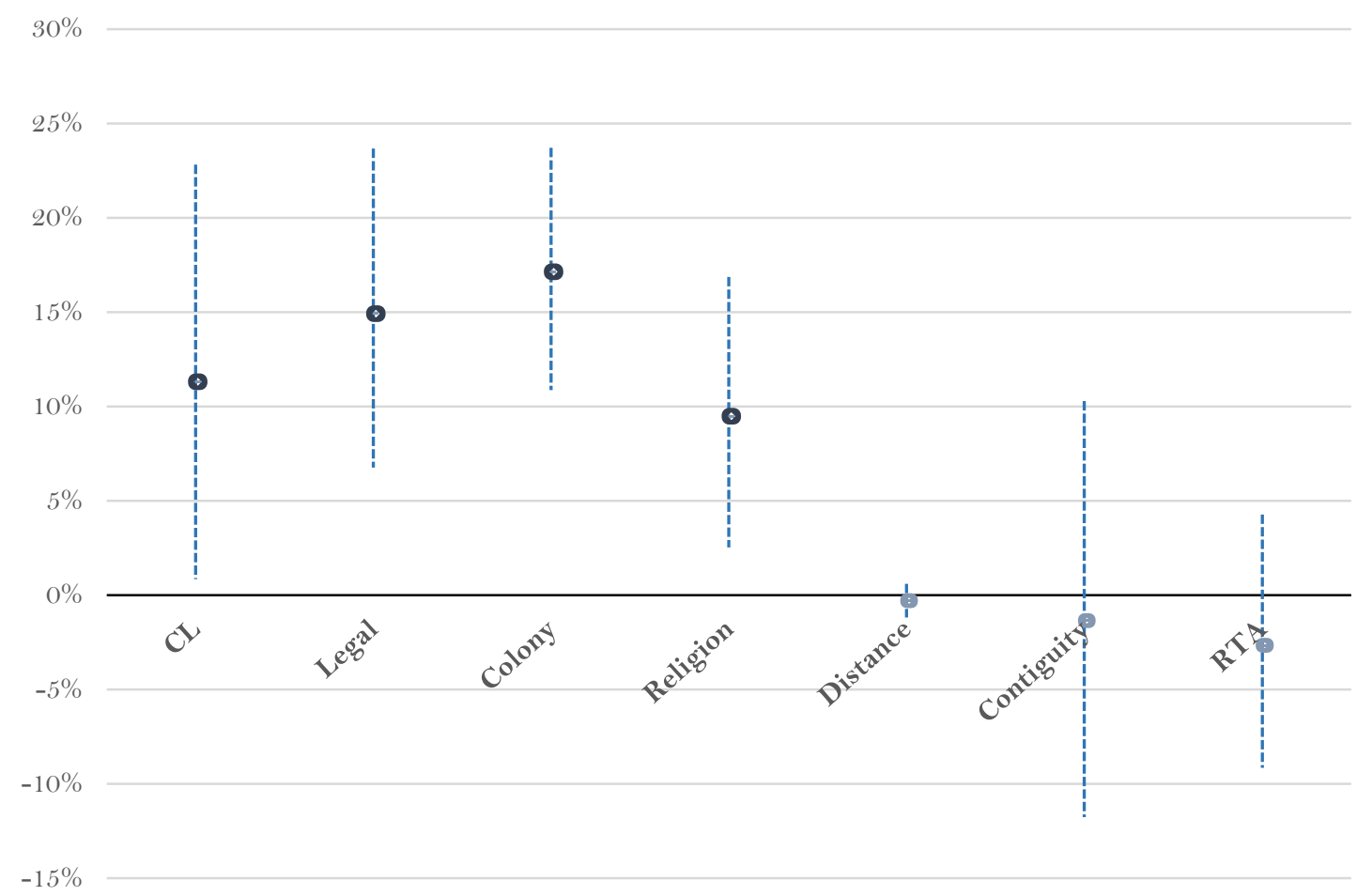

Note: The figure reports the \% change in trade induced by each variable during a recession, with the associated $90 \%$ confidence intervals computed with country-pair clustered standard errors, all other things being equal. The \% change is computed as the exponential of the associated coefficients (minus 1) corresponding coefficients are reported in table $A 3$ in the annex $A 2$. CL refers to common language and RTA to Regional Trade Agreement.

Let's focus on the common legal system element of cultural proximity. A non-significant coefficient for the interaction between common legal system and recession dummies would have implied the same "usual" additional trade flows during an economic crisis than during "normal" time for countries sharing a common legal system (compared to countries that do not share this bond). That would also mean that a given drop in demand would have generated the same relative decrease in bilateral trade flows for all country pairs, sharing or not a common legal system. In this scenario, there is no specific trade resilience. However, the additional effect of Legal $\mathrm{i}_{\mathrm{ij}}$ during an economic crisis is significantly positive: sharing a common legal system is associated with higher bilateral trade by around $15 \%{ }^{8}$ during crisis compared to what it should be with the "normal" (i.e. non-crisis) impact of legal system on trade. This is an extra-effect, crisis-specific, in addition to the already favored trade relationships these countries have in non-crisis period, all other things being equal. And the same conclusion applies for the other variables of cultural proximity: sharing a common language provides a better resilience of trade flows of around $11 \%$ when both countries experience an economic recession, sharing a common colonial past corresponds to a better resilience of $17 \%$ and sharing a common religion $9.5 \%$.

${ }^{8}\left(100 \times\left(e^{0.139}-1\right)\right)$ 
Two points need to be highlighted. First, none of the trade costs (other than cultural proxies) evidences a significant change in their coefficients during a crisis period (see table $A 3$ in annex $A 2$ ). Hence, the effects of distance, contiguity or being part of the same FTA does not vary significantly depending on the crisis status.

Second, ranking extra-effects among cultural proxies would be a daring exercise. The figure shows that the confidence interval overlaps across the different measures of cultural proximity. As already noted, the significant correlation among these variables prevents from precisely disentangling the effects of each of them on trade. Hence, the most sensible conclusion that emerges from the preceding results is that cultural proximity as a whole offers a significant better resilience of trade flows during a recession.

\subsection{Robustness tests}

To explore further the robustness of the above results, we perform a series of robustness checks that are reported in Table 2. For an easier reading, the first column reports the benchmark estimation from Table A3 - Col(1). In the second column, all countries and territories with available data are included in the estimation (for instance, we integrate small islands that are characterized by an important proportion of zero trade flows leading to a more difficult convergence of the PPML). Except for the Common language variable, no significant changes are observed.

Another reason for concern is a possible selection bias in the Recession dummy, if the distribution of this variable differs significantly across culturally proximate pairs and non-culturally proximate ones. As noted by Braun and Larrain (2005), the risk should be minimal as "Recessions (as we define them) are not likely to be concentrated in countries grouped by a particular set of characterics (e.g. political instability, openness to trade in goods, geographic location or per capita income)". This statement is confirmed in our data as at the country-pair level, the occurrence of the Recession dummy per year is very similar when comparing the whole sample with sub-samples of countrypair sharing a common language, common legal system, common colonial past or common religion (see figure $\mathrm{A} 1$ in annex $\mathrm{A} 1$ ). However, in 2001 we observe a more frequent occurrence of the recession dummy between countries sharing a common language. This is mainly due to the Hispanic (with Argentinian crisis) and the English (with the economic recession in the USA in 2001) areas. Although this possible bias should play against our results, we confront the robustness of our results by restricting the Recession dummy to the 2008/2009 financial crisis and beyond in Column 3. With this specification, the results hold and the cultural proximity coefficients are even stronger, except for the religion variable. Then, we explore different specifications of the recession dummies. In column 4, we use a dummy equal to one if the exporter is in recession in $t$ and in column 5, a dummy equal to one if the importer is in recession, irrespective of the crisis status in the partner countries. In the last column, the recession dummy is equal to one if at least one country in the pair faces a crisis. The effect of common language and colony during crises hold with these different specifications albeit with a lower magnitude. Legal system does not appear as a significant source of resilience any more if both partners are not simultaneously affected by the 
crisis and common religion does not provide extra-benefits if the affected country is the importer. Overall, these robustness checks tend to confirm the significance of cultural proximity in times of crises and particularly of common language, colonial history and common religion.

Table 2. Robustness on the dynamics in the trade impact of cultural proximity during recession, 1995-2015

\begin{tabular}{|c|c|c|c|c|c|c|}
\hline & $\begin{array}{c}(1) \\
\text { Benchmark } \\
(140 \\
\text { countries) }\end{array}$ & $\begin{array}{c}(2) \\
\text { All countries } \\
\text { and } \\
\text { territories } \\
(186)\end{array}$ & $\begin{array}{c}\text { (3) } \\
\text { Only } \\
\text { Recessions } \\
\text { in } 2009 \text { and } \\
\text { after }\end{array}$ & $\begin{array}{l}\text { (4) } \\
\text { Recessions } \\
\text { in Exporter } \\
\text { countries }\end{array}$ & $\begin{array}{l}\text { (5) } \\
\text { Recessions } \\
\text { in Importer } \\
\text { countries }\end{array}$ & $\begin{array}{c}\text { (6) } \\
\text { Recessions } \\
\text { in Imp. or } \\
\text { exp. } \\
\text { countries }\end{array}$ \\
\hline$C_{\mathrm{ij}} \cdot$ Recession $_{\mathrm{ijt}}$ & $\begin{array}{l}0.107^{*} \\
(0.0601)\end{array}$ & $\begin{array}{c}0.0973 \\
(0.0682)\end{array}$ & $\begin{array}{l}0.198^{* *} \\
(0.0817)\end{array}$ & $\begin{array}{l}0.196^{* * *} \\
(0.0432)\end{array}$ & $\begin{array}{l}0.111^{* *} \\
(0.0513)\end{array}$ & $\begin{array}{l}0.108^{* * *} \\
(0.0402)\end{array}$ \\
\hline $\begin{array}{l}\text { Legal }_{\mathrm{ij} .} \\
\text { Recession }_{\mathrm{ijt}}\end{array}$ & $\begin{array}{l}0.139 * * * \\
(0.0448)\end{array}$ & $\begin{array}{l}0.139 * * * \\
(0.0441)\end{array}$ & $\begin{array}{l}0.169 * * * \\
(0.0484)\end{array}$ & $\begin{array}{l}-0.0445 \\
(0.0293)\end{array}$ & $\begin{array}{l}-0.0360 \\
(0.0399)\end{array}$ & $\begin{array}{l}-0.0394 \\
(0.0302)\end{array}$ \\
\hline $\begin{array}{l}\text { Religion }_{\mathrm{ij} .} \\
\text { Recession }_{\mathrm{ijt}}\end{array}$ & $\begin{array}{l}0.0904^{* *} \\
(0.0399)\end{array}$ & $\begin{array}{c}0.0896^{* *} \\
(0.0396)\end{array}$ & $\begin{array}{l}0.0900 * * \\
(0.0445)\end{array}$ & $\begin{array}{c}0.0740^{* * * *} \\
(0.0268)\end{array}$ & $\begin{array}{c}0.0404 \\
(0.0265)\end{array}$ & $\begin{array}{c}0.0673^{* * *} \\
(0.0228)\end{array}$ \\
\hline $\begin{array}{l}\text { Colony }_{\mathrm{ij} \cdot} \\
\text { Recession }_{\mathrm{ijt}}\end{array}$ & $\begin{array}{l}0.158^{* * *} \\
(0.0334)\end{array}$ & $\begin{array}{l}0.143^{* * *} \\
(0.0335)\end{array}$ & $\begin{array}{l}0.163^{* * *} \\
(0.0335)\end{array}$ & $\begin{array}{l}0.159 * * * \\
(0.0335)\end{array}$ & $\begin{array}{l}0.159 * * * \\
(0.0334)\end{array}$ & $\begin{array}{l}0.160^{* * * *} \\
(0.0336)\end{array}$ \\
\hline $\begin{array}{l}\text { Observations } \\
\text { R-squared }\end{array}$ & $\begin{array}{c}407,320 \\
0.910\end{array}$ & $\begin{array}{c}685,406 \\
0.906\end{array}$ & $\begin{array}{c}407,320 \\
0.911\end{array}$ & $\begin{array}{c}407,320 \\
0.911\end{array}$ & $\begin{array}{c}407,320 \\
0.911\end{array}$ & $\begin{array}{c}407,320 \\
0.911\end{array}$ \\
\hline
\end{tabular}

Note: This table displays the results of the estimation of equation (6) with, for each of the trade costs variable, an interaction term with a time trend and with a "Recession" dummy that takes the value 1 if both the importer and exporter country are experiencing a recession in year $t$ (except in cols $3,4,5$ and 6 , see the text), estimated with PPML on a sample of 140 countries between 1995 and 2015. All regressions include the Recession dummy, origin*year and destination*year fixed effects and standard errors are clustered at the country-pair level. CL refers to Common Language. Only coefficients of interest are reported in order to save space ${ }^{* * *} p<0.01,{ }^{* *} p<0.05,{ }^{*} p<0.1$

This result clearly evidences the role of cultural proximity in dampening the trade collapse among countries sharing a cultural bond compared to countries without.

\section{Why a better resilience of trade flows among culturally proximate countries?}

The preceding results suggest a robust surge in the trade elasticity of cultural proximity language during a recession period. However, such a change in the elasticity is far from intuitive. Actually, the decrease in the import demand and/or export supply during a recession, at the origin of a trade collapse, is already controlled for through importer-year and exporter-year fixed effects. Given the multiplicative form of the gravity model, we expect that, following a drop in demand in country $i$ for goods originating from $j$, bilateral trade decreases in the same way, irrespective of the existence of a cultural bond. Although bilateral trade would still be larger among countries sharing for instance a common spoken language, all other things being equal, the decrease in trade flows 
during the economic crisis is expected to be in the same proportion compared to country pairs that do not share a common spoken language.

In other words, according to the theoretical framework, once the drop in demand/supply is controlled for, the trade elasticity to cultural proximity (CP), expressed as $\bar{\kappa}_{x}=(\sigma-1)(\alpha+\pi) \kappa_{x}$ in equation (6), should be constant over time. ${ }^{9}$

To explain the divergence between our empirical results and the predictions of the model, two sets of explanations emerge:

(i) Parameters are constant but product-specific; this is by definition the case of $\sigma$ (degree of elasticity of substitution between all varieties of a good) but also of $\pi$ (the trade cost elasticity to cultural proximity) and $\alpha$ (the consumer preference elasticity to cultural proximity). Then, the increase in the effect of cultural proximity on aggregate trade could be due to a pure composition effect. This hypothesis is tested in section 4.1.

(ii) Parameters are not constant in a crisis context. In section 4.2, we survey existing evidence in the recent literature about an "overreaction" of trade flows to GDP drop, developed since the financial crisis of 2008/2009.

\subsection{Trade composition effect}

As developed in equation (6) the impact of a cultural proximity variable on trade depends on the type of goods through three parameters: $\sigma, \pi$ and $\alpha$. This phenomenon appears clearly in Table 1: the coefficient $\bar{\kappa}_{x, p}=\left(\sigma_{p}-1\right)\left(\alpha_{p}+\pi_{p}\right) \kappa_{x}$ is significantly higher for $\mathrm{p}=$ differentiated goods than for $p=$ homogenous goods (according to the Rauch decomposition) in case of $x=\left\{C L_{i j} ;\right.$ Legal $_{i j} ;$ Religion $\left._{i j}\right\}$. Then, even with constant parameters during an economic crisis, a simple change in the trade composition during the trade collapse between countries sharing a cultural characteristic, in favor of more differentiated goods, will mechanically generate an increase in the associated cultural proximity coefficient.

Figure 3 reports the evolution in the trade composition when an economic crisis occurs. More precisely, we report the share of differentiated goods in total trade, on average during "normal" time and Recession years. We report difference in averages for the whole sample but also for the sub-samples of country pairs sharing a common language, a common legal system, a common religion and a common colonial past. We also indicate with a star when difference in averages is significant at the $1 \%$ level.

\footnotetext{
${ }^{9}$ The same conclusion applies when considering a gravity equation with intensive and extensive margins à la Chaney (2008) or Crozet and Koenig (2008). Even if cultural proximity is expected to provide some extra-trade at both margins, a drop in demand will have the same proportional effect whether countries share cultural characteristics or not.
} 
Figure 3: evolution of the share of differentiated goods in total trade during crisis time, 1995-2015

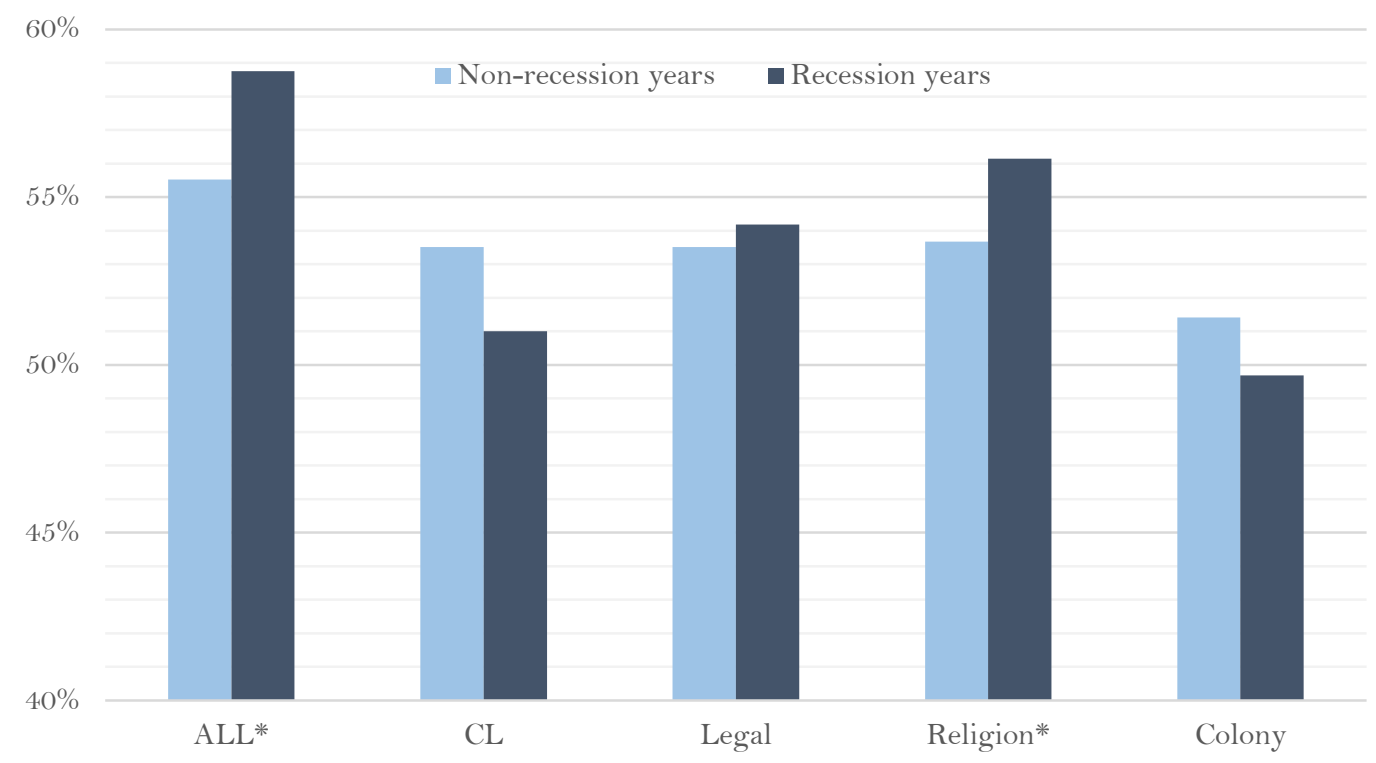

Note: * denotes mean difference significant at the $1 \%$ level. $\mathrm{CL}$ refers to Common Language.

According to Figure 3 there is no evidence that countries sharing a cultural bond experience a significant change in their trade composition during the crisis years, which dampen the possibility of a pure composition effect as an explanation of the surge in the impact of cultural proximity on trade during recession period.

Second, when looking at the trend within category of products (one equation by type of goods according to Rauch), the better resilience of trade among countries sharing a cultural bond remains for differentiated products as opposed to homogenous products for Common language, Common legal system and Colony as shown in table A3 in annex A2. Coefficients of interest are summarized in Figure 4. This effect is consistent with Rauch (1999) that emphasized the relevance of network/search model to describe trade in differentiated products, as opposed to homogeneous and reference priced. The many dimensions accounting for the price of a differentiated product render international commodity arbitrage impossible and therefore require the trader to engage in a sequential search between buyers and sellers. This matching process is facilitated by the existence of cultural ties enabling a better knowledge of the market and influencing the composition of the traders' network. Therefore, cultural proximity and search costs in general should have the greatest impact on differentiated products. 


\section{Figure 4: Dynamic in the trade impact of Cultural Proximity during Recession, within Rauch category, 1995-2015}

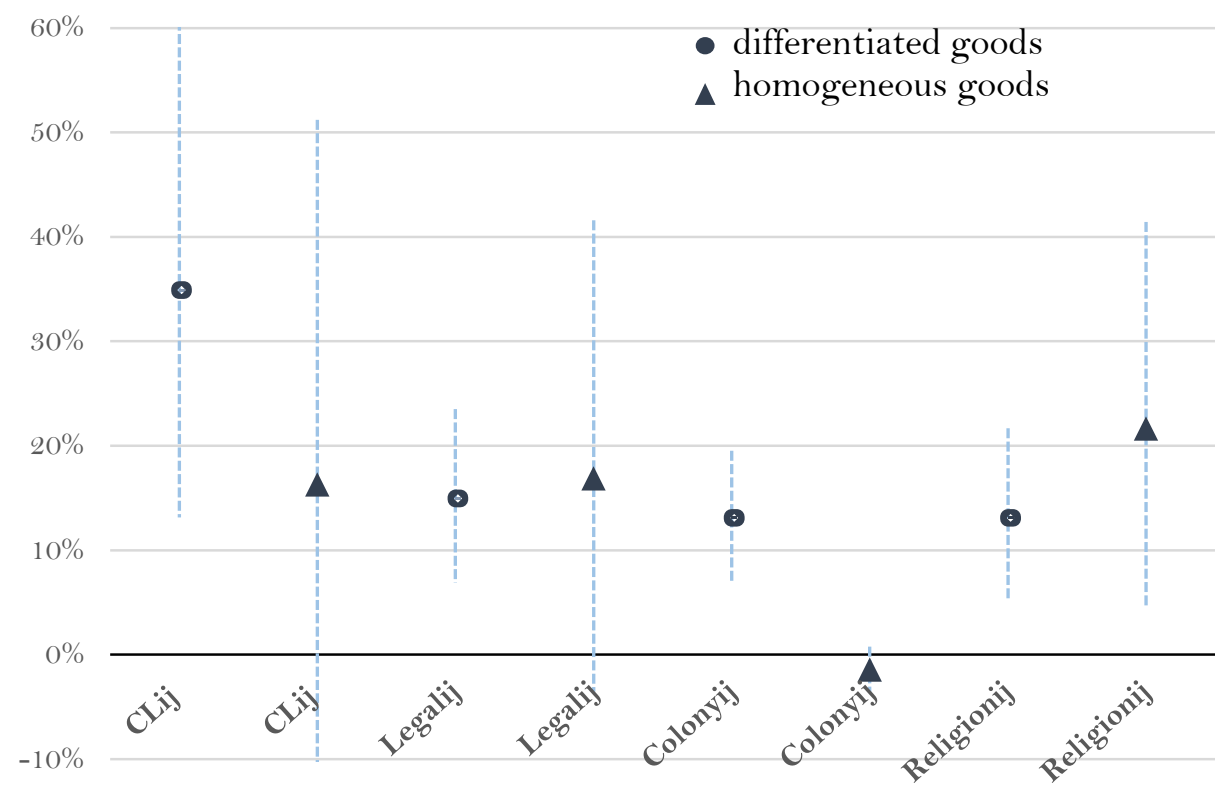

Note: The figure reports the \% change in trade induced by each variable during a recession, with the associated $90 \%$ confidence intervals computed with country-pair clustered standard errors, all other things being equal. The \% change is computed as the exponential of the associated coefficients (minus 1 ) - corresponding coefficients are reported in table A3 in the annex A2. CL refers to Common Language.

All these results corroborate that something is happening beyond a composition effect.

\subsection{Beyond the standard gravity model}

In recent years, it has been clearly stated that gravity model cannot explain the disproportionate decline in trade except if we assume large increase in bilateral trade costs. However, it seems that such increase in protectionism from trade policies did not happen (e.g. Kee et al. 2013). But other trade frictions, such as the drying up of trade credit and the rising uncertainty could explain why the decline in international trade was so large compared to the decrease in output. Such trade frictions are imperfectly captured by the gravity if they are not exporter-year or importer-year specific. We argue that cultural proximity may affect some of the determinants highlighted in the literature, thereby inducing a differential in the trade collapse among country pairs. In order to go one-step further in the understanding of the results, we propose in this section a survey geared towards the potential underlying mechanisms of the surge in the cultural proximity effect during an economic crisis, and more specifically during the financial crisis of 2008/2009.

\section{Crisis and the trade cost elasticity to cultural proximity $(\alpha)$}

On the importer side, Novy \& Taylor (2014) combine the "uncertainty shock" - defined by Bloom (2009) as an event that increases the uncertainty about the future path of the economy - with a model of international trade. They show that, after a large uncertainty shock in business condition, 
firms adopt a "wait-and-see" approach and postpone (or cut) their orders for foreign intermediate goods disproportionately compared to domestic intermediates orders. This is due to the existence of fixed costs of ordering associated with trade costs. At the aggregate level, this leads to a more important contraction in international trade than in domestic trade (and then production) and a stronger recovery. In such a context, the lower the fixed costs of ordering from a given country, the less reluctant firms are to order intermediate inputs from this country if uncertainty rises. If we assume that a common language involves lower fixed costs, the rise of uncertainty following the financial crisis after the collapse of Lehman Brothers (September 2008) can explain a better resilience of trade flows between countries sharing a common language. Moreover, given the Novy \& Taylor (2014)'s model, this effect should be stronger for durable goods, for which the wait-andsee response is easier than for goods with higher depreciation rate. This joins the conclusion of Eaton et al. (2016). For these authors, the decline in the efficiency of investment in durable manufactures, an intensively traded sector, was one of the major driver of the overall collapse in trade. Following Engel \& Wang (2011), we re-estimate our main specification using the durable / non-durable classification and focusing on the 2008/2009 financial crisis - the "Recession" dummy takes the value 1 if both the importer and exporter country are experiencing a recession in 2009 and after. Based on the results reported in Table 3, the surge in the cultural proximity variables holds for both durable and non-durable goods (with the exception of common language), ruling out once again the hypothesis that the trade resilience induced by cultural proximity is driven by a pure composition effect. Another noteworthy results from this table is the better resilience of trade in durable goods during the recession for the pairs sharing a cultural bond. Given that trade in durable goods has been identified in the literature as an important driver of the overall trade collapse in 2009, a better resilience of these trade flows constitutes a substantial economic advantage. 
Table 3. Cultural proximity and trade during recession across durable/nondurable products, 1995-2015

\begin{tabular}{|c|c|c|}
\hline Trade flows & $\begin{array}{c}\text { (1) } \\
\text { Durable } \\
\text { goods }\end{array}$ & $\begin{array}{c}\text { (2) } \\
\text { Non Durable } \\
\text { goods }\end{array}$ \\
\hline $\mathrm{CL}_{\mathrm{ij},}$ Recession ${ }_{\mathrm{ijt}}$ & $\begin{array}{c}0.0709 \\
(0.0886)\end{array}$ & $\begin{array}{c}0.326^{* * *} \\
(0.104)\end{array}$ \\
\hline Legalij. $_{\text {. Recession }}{ }_{\mathrm{ijt}}$ & $\begin{array}{l}0.174^{* * * *} \\
(0.0501)\end{array}$ & $\begin{array}{l}0.141^{* *} \\
(0.0651)\end{array}$ \\
\hline Religion $_{\mathrm{ij} .}$ Recession ${ }_{\mathrm{ijt}}$ & $\begin{array}{l}0.0996^{* *} \\
(0.0489)\end{array}$ & $\begin{array}{l}0.0972^{*} \\
(0.0533)\end{array}$ \\
\hline Colony $_{\mathrm{ij} .}$ Recession ${ }_{\mathrm{ijt}}$ & $\begin{array}{l}0.182^{* * * *} \\
(0.0343)\end{array}$ & $\begin{array}{l}0.128^{* * * *} \\
(0.0368)\end{array}$ \\
\hline Observations & 407,320 & 407,320 \\
\hline R-squared & 0.932 & 0.827 \\
\hline
\end{tabular}

Note: This table displays the results of the estimation of equation (6) with, for each of the trade costs variable, an interaction term with a time trend and with a "Recession" dummy that takes the value 1 if both the importer and exporter country are experiencing a recession in 2009 and after, estimated with PPML on a sample of 140 countries between 1995 and 2015. The durable/Non durable classification is based on Engel \& Wang (2011). All regressions include the Recession dummy, origin*year and destination*year fixed effects and standard errors are clustered at the country-pair level. CL refers to common language. Only coefficients of interest are reported in order to save space. ${ }^{* *} p<0.01,{ }^{* *} p<0.05,{ }^{*} p<0.1$

On the exporter side, both Chor \& Manova (2012) and Amiti \& Weinstein (2011) link the trade collapse to a tightening in trade credit. Amiti \& Weinstein (2011) demonstrate that the health of banks has a much larger effect on exports than on domestic sales, thus establishing that financial shocks affect exports and domestic sales differently. Two channels associated with international trade are identified: higher default risk and higher working capital requirements. The latter is due to longer time lags associated with international trade, especially when shipping by sea. The former refers to an increased need to insure against credit default risk as exporters rarely have the capacity to evaluate default risk and usually turn to banks to provide payment insurance and guarantees. Once again, one can imagine than this mechanism can be dampened among culturally proximate countries, supposed to better capture cultural affinities like values and norms, and potentially more trust. In this case, one can imagine that the decline in bank health would have a smaller impact on the exports of firms (where default risk is a smaller issue). This could be in line with one test proposed by Amity \& Weinstein (2011): the presence of foreign affiliates in a country implied for the associated firms a lower impact on the exports during the crisis, thanks to better information and then a lower need of bank insurance.

More generally, according to Mishkin (2003) financial crisis can be interpreted as "a disruption to financial markets in which adverse selection and moral hazard problems become much worse, so that financial markets are unable to efficiently channel funds to those who have the most productive investment opportunities." This implies that cultural proximity may play a particular 
role in times of crisis, reducing adverse selection and moral hazard. This concept has been notably explored in international business and management literature, through the concept of "psychic distance" (e.g. Zhu, L. \& Yang, J. 2008).

\section{Crisis and the consumer preference elasticity to cultural proximity $(\pi)$.}

Another venue for explaining the better resilience of trade flows among culturally proximate countries during the crisis deals with the consumer side and more precisely, with the consumer preferences' elasticity to cultural proximity in our model. There exists, to our knowledge, little evidence in the literature about a possible evolution of the elasticity of consumer preferences to cultural proximity, a notable exception being the strand of the management and marketing literature dealing with "consumer ethnocentrism and animosity". More related to our research are the studies analyzing how consumers' perception and intentions may vary in times of crises (Leong et al, 2008; Maher \& Mady., 2010; Ma et al., 2012; Smyczek \& Glowik, 2012). Some papers from this literature have evidenced the impact of international crises, being diplomatic or economic, on the subjective perception of the consumers and their eventual consumption behavior. Relying on a study of the Polish market, Smyczek \& Glowik (2012) have highlighted the shift in consumers' behavior toward ethnocentric stance and "animosity" against foreign products during the economic crisis. Watson and Wright (2000) showed that consumer ethnocentrism tend to be mitigated for products originating from culturally similar countries (measured as the sharing of common values). Another study done by Ma et al. (2012) emphasizes the moderating effect of cultural similarity between two countries in the negative consumers' product judgment and willingness to buy foreign products. Altogether, this strand of research suggests that consumers' behavior and perception toward foreign product may have evolved (negatively) during the financial crisis; but this effect may have been mitigated for culturally similar country pairs. In our model, this hypothesis would translate in a $\pi$ varying (negatively) in times of crisis and across partners (to a lower extent for culturally proximate countries).

\section{Concluding remarks}

In the aftermath of the crisis, some countries have displayed their willingness to invigorate their trade relationships with partners sharing a cultural bond with them as a way to alleviate the effects of the financial crisis. ${ }^{10}$ In this paper, we investigated empirically whether cultural proximity has been a source of trade resilience during the crisis. In line with the trade literature, we use various proxies for measuring cultural proximity between countries: namely, common language, common colonial history, legal system and common religion.

Relying on the estimation of structural gravity equation on the bilateral trade flows for a large sample of countries during the 1995-2015 period, the results uncovered the significant surge in the

\footnotetext{
${ }^{10}$ Several initiatives aiming at strengthening trade relationships among countries sharing a common cultural heritage during crises have been recently launched such as the Francophonie Economic Forum and the renewed Portuguese efforts to deepen and strengthen ties with Lusophone countries in the aftermath of the crisis (Ashby 2017, Flores 2011).
} 
effect of cultural proximity variables during a crisis. The additional effect of cultural proximity variables on bilateral trade flows during an economic crisis compared to its expected level in "normal" (i.e. non-crisis) period ranges between $9.5 \%$ (for common religion) and 17\% (for a common colonial past).

While this effect could be driven by a pure composition effect, i.e. culturally proximate countries trade certain goods that have been less impacted by the crisis, we find no evidence that these countries have experienced a drastic change in their trade composition during the trade collapse in 2009 and the results obtained from the estimation within category of products also ruled out that the underlying mechanism is a pure composition effect. To go further in the understanding of the results, we provide a discussion of the mechanisms that can be at play, based on the theoretical framework and various contributions in the literature, for explaining the better resilience of trade among countries sharing a cultural bond. These determinants involve the mitigating influence of cultural proximity on different determinants of the trade collapse: the uncertainty shock, the increased moral hazard among trading partners or the ethnocentric sentiment developed by the consumers in the aftermath of the crisis.

\section{References}

- Amiti, M., and Weinstein D. (2011). Exports and financial shocks. Quarterly Journal of Economics, 126(4), 1841-1877.

- Ashby, S. (2017). The Lusophone world. The evolution of Portuguese national narratives. Sussex, UK: Sussex Academic Press.

- Bloom, N. (2009). The impact of uncertainty shocks. Econometrica 77(3), 623-685.

- Braun, M., and Larrain, B. (2005). Finance and the business cycle: international, inter-industry evidence. The Journal of Finance, 60, 1097-1128.

- Campbell, D., Meissner, C., Novy, D., and Jacks D. (2009). Explaining two trade busts: output vs. trade costs in the Great Depression and today. VoxEU.org, 19 September.
- Carrère, C., and Masood, M. (2015). Poids économique de la francophonie : impact via l'ouverture commerciale. Revue d'économie du développement, 23(2), 530.

- Chaney, T. (2008). Distorted gravity: the intensive and extensive margins of international trade. The American Economic Review, 98(4), 1707-1721.

- Chor, D., and Manova, K., (2012). Off the cliff and back? Credit conditions and international trade during the global financial crisis. Journal of International Economics, 87(1), 117-133.

- Combes, P.-P., Lafourcade, M., and Mayer, T. (2005). The trade-creating effects of business and social networks: evidence from France. Journal of international Economics, 66(1), 1-29.

- Crozet, M., and Koenig, P. (2010). Structural gravity equations with intensive and extensive margins. Canadian Journal of Economics/Revue canadienne d'économique, 43, 41-62. 
- Eaton, J., Kortum, S., Neiman B., and Romalis, J. (2016). Trade and the global recession. American Economic Review, 106(11), 3401-3

- Egger, P. H., and Lassmann, A. (2012). The language effect in international trade: $A$ meta-analysis. Economics Letters, 116(2), 221-224.

- Egger, P. H., and Toubal, F. (2016). Common spoken languages and international trade. In The Palgrave Handbook of Economics and Language, pp. 263-289.

- Eichengreen, B., and O'Rourke K. H. (2010). A tale for two depressions. VoxEU.org, 8 March.

- Engel, C., and Wang, J. (2011). International trade in durable goods: Understanding volatility, cyclicality, and elasticities. Journal of International Economics, 83(1), 37-52.

- Felbermayr, G. J., and Toubal, F. (2010). Cultural proximity and trade. European Economic Review, 54(2), 279-293.

- Flores, R. G. (2011). While the crisis proceeds: A world redistribution of economic power? Working papers, Universidade Nova de Lisboa, Faculdade de Economia.

- Gaulier, G., and Zignago, S. (2010). Baci: International trade database at the product-level. the 1994-2007 version. Working Papers 2010-23, CEPII. URL: http://www.cepii.fr/CEPII/fr/publications/ wp/abstract.asp?NoDoc $=2726$

- Glaeser, E. L., and Shleifer, A. (2002). Legal origins. The Quarterly Journal of Economics, 117(4) pp. 1193-1229.

- Guiso, L., Sapienza, P., and Zingales, L. (2009). Cultural biases in economic exchange. The Quarterly Journal of Economics, 124(3), 1095-1131.
- Head, K., and Mayer, T. (2014). Gravity equations: Workhorse, toolkit, and cookbook. In Handbook of International Economics, 4.

- Head, K., Mayer, T., and Ries, J. (2010). The erosion of colonial trade linkages after independence. Journal of international Economics, 81(1), 1-14.

- Helpman, E., Melitz, M., and Rubinstein, Y. (2008). Estimating trade flows: Trading partners and trading volumes. The Quarterly Journal of Economics, 123(2), 441-487.

- Kee, H. L., Neagu, C., and Nicita, A., (2013). Is protectionism on the rise? Assessing national trade policies during the crisis of 2008. Review of Economics and Statistics, 95(1), 342-356.

- Leong, S.M., Cote, J.A., Ang, S.H., and al. (2008). Understanding consumer animosity in an international crisis: Nature, antecedents, and consequences. Journal of International Business Studies, 39(6), 996-1009.

- Ma, J., Wang, S., and Hao, W. (2012). Does cultural similarity matter? Extending the animosity model from a new perspective. Journal of Consumer Marketing, 29(5), 319-332.

- Maher, A.A., and Mady, S. (2010). Animosity, subjective norms, and anticipated emotions during an international crisis. International Marketing Review, 27(6), 630-651.

- Mayer, T., and Zignago, S. (2011). Notes on CEPII distances measures: The geodist database. Working Papers 2011-25, CEPII. URL:

http://www.cepii.fr/CEPII/en/publications/ wp/abstract.asp?NoDoc $=3877$

- Melitz, J. (2008), Language and foreign trade. European Economic Review, 52(4), 667-699. 
- Melitz, J., and Toubal, F. (2014). Native language, spoken language, translation and trade. Journal of International Economics, 93(2), 351-363.

- Melitz, M.J. (2003). The impact of trade on intra-industry reallocations and aggregate industry productivity, Econometrica, 71(6), 1695-1725.

- Mishkin, F.S. (2003). Financial policies and the prevention of financial crises in emerging market countries. In: Feldstein, M. (Ed.), Economic and Financial Crises in Emerging Market Countries. Chicago, IL: University of Chicago Press.

- Novy, D., and Taylor A.M. (2014). Trade and uncertainty, NBER Working Paper 19941.
- Olivier, J., Thoenig, M., and Verdier, T. (2008). Globalization and the dynamics of cultural identity. Journal of international Economics, 76(2), 356-370.

- Rauch, J.E. (1999). Networks versus markets in international trade, Journal of international Economics, 48(1), 7-35.

- Smyczek, S., and Glowik, M. (2011). Ethnocentrism of Polish consumers as a result of the global economic crisis. Journal of Customer Behaviour, 10(2), 99118.

- Watson, J.J., and Wright, K. (2000). Consumer ethnocentrism and attitudes toward domestic and foreign products. European journal of Marketing, 34(9/10), 1149-1166.

- Zhu, L., and Yang, J. (2008). The role of psychic distance in contagion: a gravity model for contagious financial crises. Journal of Behavioral Finance, 9(4), 209223. 


\section{Annex A1: Source, computation and descriptive statistics}

Trade and some trade costs variables. Data about bilateral trade flows are retrieved from the BACI (Base d'analyse du commerce international) dataset constructed by CEPII (Gaulier \& Zignago 2010) based on the UN COMTRADE database. The BACl version is more suited (compared to other sources like DOTS from the IMF or COMTRADE from the UN) to trade analyses comprising a wide range of countries and notably including a large number of developing countries. The $\mathrm{BACl}$ database allows accounting for a larger number of observations as it systematically matches the declaration of both reporter and partner using the mirror data approach. ${ }^{11}$ We focus on the 140 countries with available data and more than 1 million inhabitants over the sample period. The other bilateral gravity variables, namely distance, contiguity, and the existence of a preferential trade agreement are also retrieved from the CEPII website (Mayer \& Zignago 2011) and summarized in Table A1.

The linguistic and colony variables. We use the typical "Common language" dummy equals to one if two countries share a common official language and/or if a common language is spoken by at least $9 \%$ of the population (from Mayer \& Zignago 2011). We aggregate in the colony dummy countries that have a common colonial past (either an hegemonic relationship or a common colonizer).

The common religion variable. The religion variable was collected from Mayer \& Zignago (2008)'s dataset (originally from Helpman et al. (2008)). This variable measures the probability that two randomly drawn persons, one from each country, share the same religion as follows:

Religion $_{i j}=\left(\%\right.$ Protestants $_{i} . \%$ Protestant $\left._{j}\right)+\left(\%\right.$ Catholics $_{i} . \%$ Catholics $\left._{j}\right)+\left(\%\right.$ Muslims $_{i} . \%$ Muslims $\left.s_{j}\right)$

We transform this percentage in a dummy variable equal to one when is higher than $30 \%, 0$ otherwise ( $30 \%$ being the median for country pairs with a non-zero Religion $\mathrm{n}_{\mathrm{ij}}$ )

The common legal system variable. The construction of the common legal system variable relies on data provided by Mayer \& Zignago (2008) (originally taken from Glaeser \& Shleifer, 2002). This variable indicates whether the countries in the pair share the same legal system. In this classification, there are four types of legal system: english / french / german or scandinavian.

Recession Dummy. This is a dummy variable indicating whether a country pair is experiencing a recession in a particular year. To identify countries experiencing a recession in $t$ we follow Braun \& Larrain (2005) and identify, for each country, troughs as years when the current logarithm of real local currency GDP (from World Bank, 2017) deviates by more than one standard deviation from its trend level (computed using the Hodrick-Prescott filter with a smoothing parameter of 100). For each trough, a local peak is defined as the closest preceding year for which cyclical GDP (the difference between actual and trend values) is higher than during the previous and posterior years.

\footnotetext{
${ }^{11}$ The reader can refer to Gaulier \& Zignago (2010) for more details on the construction of the BACI dataset.
} 
The recession variable per country takes a value of 1 all the years between peak and trough (excluding the peak year), and is 0 otherwise. The cyclical component of the GDP is constructed with data from 1990 to 2015, whenever available. The recession dummy is assigned a missing value if there is no GDP data.

Table A1: Descriptive statistics (407,320 observations)

\begin{tabular}{lccccc}
\hline Variables & Obs & Mean & Std. Dev. & Min & Max \\
\hline Common spoken language & 407,320 & $\mathbf{0 . 1 2 2}$ & 0.327 & 0 & 1 \\
Common official language & 407,320 & $\mathbf{0 . 1 1 7}$ & 0.321 & 0 & 1 \\
Common legal system & 407,320 & $\mathbf{0 . 4 1 7}$ & 0.493 & 0 & 1 \\
Common religion & 407,320 & $\mathbf{0 . 1 9 2}$ & 0.394 & 0 & 1 \\
Common colonial past & 407,320 & $\mathbf{0 . 0 8 4}$ & 0.278 & 0 & 1 \\
Distance & 407,320 & $\mathbf{7 2 5 9 . 4}$ & 4241.8 & 114.6 & 19650.1 \\
Common border & 407,320 & $\mathbf{0 . 0 2 4}$ & 0.154 & 0 & 1 \\
FTA & 407,320 & $\mathbf{0 . 1}$ & 0.3 & 0 & 1 \\
Recession & 407,320 & $\mathbf{0 . 0 1 3}$ & 0.113 & 0 & 1 \\
\hline
\end{tabular}

Table A2: Correlation matrix (407,320 observations)

\begin{tabular}{lcccccccc}
\hline Variables & CLspoken & CLofficial & Legal & Religion & Colony & Dist & Contig & RTA \\
\hline $\begin{array}{l}\text { Common spoken } \\
\text { language }\end{array}$ & 1 & & & & & & & \\
$\begin{array}{l}\text { Common official } \\
\text { language }\end{array}$ & $0.8021^{*}$ & 1 & & & & & & \\
Common legal system & $0.1876^{*}$ & $0.2701^{*}$ & 1 & & & & & \\
Common religion & $0.1337^{*}$ & $0.1588^{*}$ & $0.1602^{*}$ & 1 & & & & \\
Common colonial past & $0.3228^{*}$ & $0.3596^{*}$ & $0.2170^{*}$ & $0.0181^{*}$ & 1 & & & \\
Distance & $-0.1329^{*}$ & $-0.1375^{*}$ & $-0.0271^{*}$ & $-0.1304^{*}$ & $-0.1431^{*}$ & 1 & & \\
Common border & $0.1392^{*}$ & $0.1452^{*}$ & $0.0674^{*}$ & $0.1173^{*}$ & $0.1576^{*}$ & $-0.2274^{*}$ & 1 & \\
RTA & $0.1198^{*}$ & $0.1070^{*}$ & -0.001 & $0.1269^{*}$ & $0.0963^{*}$ & $-0.3636^{*}$ & $0.2651^{*}$ & 1 \\
Recession & 0.0023 & 0.0023 & $-0.0179^{*}$ & $0.0145^{*}$ & $-0.0100^{*}$ & $-0.0126^{*}$ & $0.0141^{*}$ & $0.0653^{*}$ \\
\hline
\end{tabular}

* denotes correlations significant at the $1 \%$ level. 
Figure A1. Occurrence of the Recession dummy per year and cultural proxies, 1995-2015

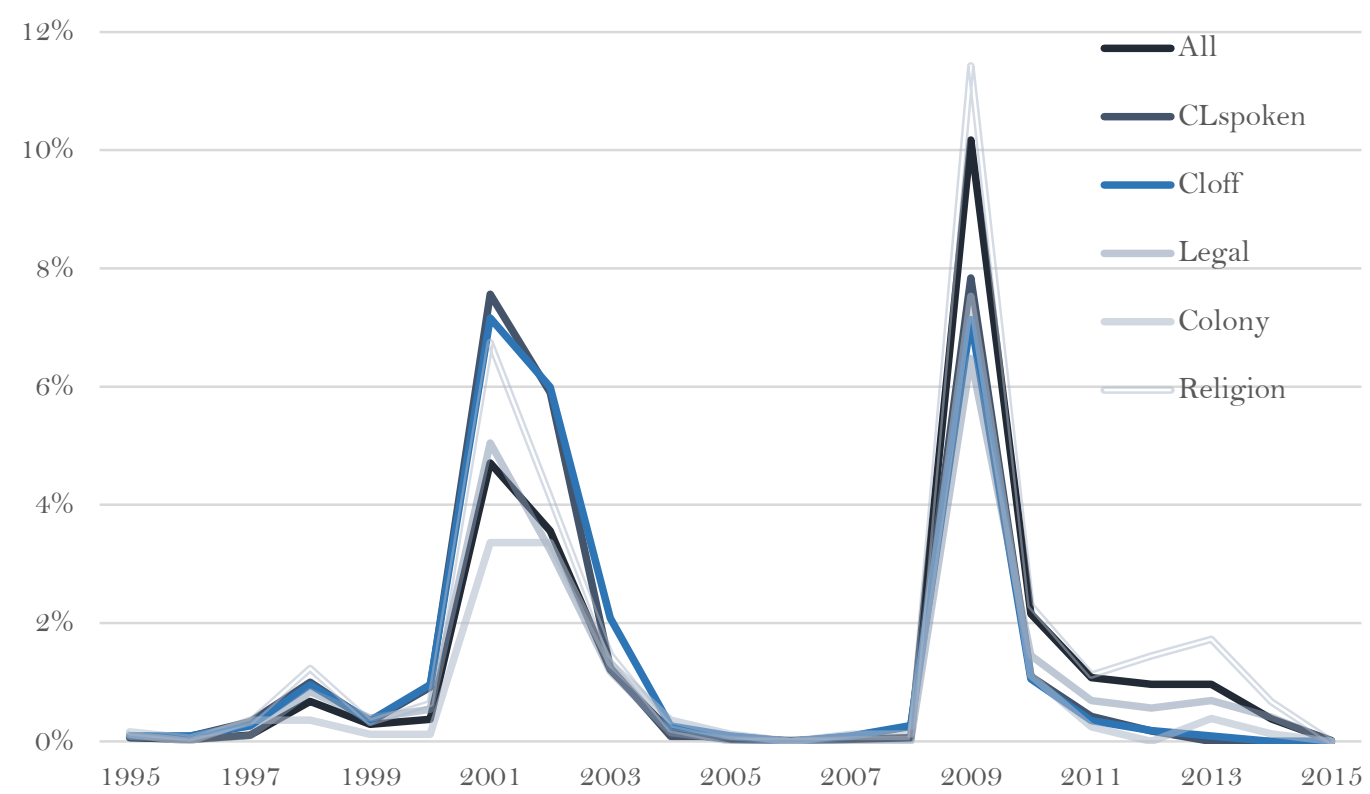

Note: "All" is the occurrence of the Recession dummy in our sample (407,320 observations), "CLspoken" is the occurrence of the Recession dummy within the subsample of country-pairs that share a common spoken language, etc. 
Annex A2: Dynamics in the trade impact of cultural proximity and trade costs during recession, 1995-2015

Table A3. Dynamics in the trade impact of cultural proximity and trade costs during recession, 19952015
(1)
(2)
(3)
(4)

\begin{tabular}{|c|c|c|c|c|}
\hline Trade flows & All goods & Differentiated & Referenced price & Homogeneous \\
\hline \multicolumn{5}{|c|}{ Cultural Proximity variables } \\
\hline \multirow[t]{2}{*}{$\mathrm{CL}_{\mathrm{ij}}$} & $0.247^{* * *}$ & $0.258^{* * *}$ & $0.125^{* * *}$ & $0.220^{* * *}$ \\
\hline & $(0.0331)$ & $(0.0351)$ & $(0.0364)$ & $(0.0647)$ \\
\hline \multirow[t]{2}{*}{$\mathrm{CL}_{\mathrm{ij} \cdot} \cdot$ Recession $\mathrm{ijt}$} & $0.107^{*}$ & $0.299 * * *$ & 0.0240 & 0.151 \\
\hline & $(0.0601)$ & $(0.107)$ & $(0.0699)$ & $(0.160)$ \\
\hline \multirow[t]{2}{*}{$\mathrm{CL}_{\mathrm{ij}}$. trend $\mathrm{t}_{\mathrm{t}}$} & $-0.0102^{* * *}$ & $-0.0106^{* * *}$ & $-0.00935^{* * *}$ & -0.00262 \\
\hline & $(0.00260)$ & $(0.00267)$ & $(0.00278)$ & $(0.00518)$ \\
\hline \multirow[t]{2}{*}{ Legal $_{\mathrm{ij}}$} & $0.199 * * *$ & $0.223^{* * *}$ & $0.176^{* * *}$ & $0.226^{* * *}$ \\
\hline & $(0.0206)$ & $(0.0213)$ & $(0.0218)$ & $(0.0411)$ \\
\hline \multirow[t]{2}{*}{ Legal $_{\mathrm{ij} \cdot}$. Recession ${ }_{\mathrm{ijt}}$} & $0.139 * * *$ & $0.112^{* *}$ & 0.0736 & 0.156 \\
\hline & $(0.0448)$ & $(0.0441)$ & $(0.0462)$ & $(0.117)$ \\
\hline \multirow[t]{2}{*}{ Legal $_{\mathrm{ij} \text {. }}$ trend $\mathrm{t}_{\mathrm{t}}$} & -0.00252 & 0.00114 & -0.00214 & $-0.00799 * *$ \\
\hline & $(0.00163)$ & $(0.00163)$ & $(0.00175)$ & $(0.00321)$ \\
\hline \multirow[t]{2}{*}{ Religion $_{\mathrm{ij}}$} & -0.0324 & $-0.0435^{*}$ & 0.0143 & -0.0356 \\
\hline & $(0.0215)$ & $(0.0238)$ & $(0.0260)$ & $(0.0474)$ \\
\hline \multirow[t]{2}{*}{ Religion $_{\mathrm{ij} \cdot}$. Recession $\mathrm{ijt}_{\mathrm{jt}}$} & $0.0904^{* *}$ & $0.123^{* * *}$ & 0.0182 & $0.196^{* *}$ \\
\hline & (0.0399) & $(0.0446)$ & $(0.0507)$ & $(0.0919)$ \\
\hline \multirow[t]{2}{*}{ Religion $_{\mathrm{ij} .}$ trend $_{\mathrm{t}}$} & $-0.00496^{* * *}$ & $-5.37 e-05$ & $0.00337^{*}$ & $-0.0233^{* * *}$ \\
\hline & $(0.00178)$ & $(0.00189)$ & $(0.00205)$ & $(0.00400)$ \\
\hline \multirow[t]{2}{*}{ Colony $_{i j}$} & -0.0297 & $-0.116^{* * *}$ & $0.0879^{*}$ & $0.396^{* * *}$ \\
\hline & $(0.0432)$ & $(0.0436)$ & $(0.0482)$ & $(0.0682)$ \\
\hline \multirow[t]{2}{*}{ Colony $_{\mathrm{ij} \cdot}$ Recession ${ }_{\mathrm{ijt}}$} & $0.158 * * *$ & $0.123^{* * *}$ & $0.188^{* * *}$ & -0.0143 \\
\hline & $(0.0334)$ & $(0.0338)$ & $(0.0367)$ & $(0.0135)$ \\
\hline \multirow[t]{2}{*}{ Colony $_{\mathrm{ij} \text {. }}$ trend $_{\mathrm{t}}$} & $-0.0331^{* * *}$ & $-0.0275^{* * *}$ & $-0.0448^{* * *}$ & 0.00340 \\
\hline & $(0.00794)$ & $(0.00810)$ & $(0.0105)$ & $(0.0515)$ \\
\hline \multicolumn{5}{|l|}{ Other trade costs } \\
\hline \multirow[t]{2}{*}{ Distij $_{i j}$} & $-0.631^{* * * *}$ & $-0.575^{* * *}$ & $-0.783^{* * * *}$ & $-1.137^{* * * *}$ \\
\hline & $(0.0190)$ & $(0.0195)$ & $(0.0215)$ & $(0.0385)$ \\
\hline \multirow[t]{2}{*}{ Dist $_{\mathrm{ij} .}$. Recession $\mathrm{ijt}_{\mathrm{jt}}$} & -0.00288 & $-0.0101^{*}$ & 0.000115 & 0.0164 \\
\hline & $(0.00546)$ & $(0.00556)$ & $(0.00604)$ & $(0.0109)$ \\
\hline \multirow[t]{2}{*}{ Dist $_{\mathrm{ij} .}$. trend $_{\mathrm{t}}$} & $-0.00517^{* * *}$ & $-0.00657^{* * *}$ & 0.000542 & $0.00822^{* * *}$ \\
\hline & $(0.00143)$ & $(0.00149)$ & $(0.00158)$ & $(0.00310)$ \\
\hline \multirow[t]{2}{*}{ Contig $g_{i j}$} & $0.432^{* * *}$ & $0.462^{* * *}$ & $0.331^{* * *}$ & $0.336^{* * *}$ \\
\hline & $(0.0326)$ & $(0.0359)$ & $(0.0321)$ & $(0.0655)$ \\
\hline \multirow[t]{2}{*}{ Contigij. Recession ${ }_{\mathrm{ijt}}$} & -0.0135 & 0.0745 & -0.0726 & -0.104 \\
\hline & $(0.0680)$ & $(0.0740)$ & $(0.0919)$ & $(0.148)$ \\
\hline \multirow[t]{2}{*}{ Contig $\mathrm{gij}_{\mathrm{j}}$ trend } & $-0.00617^{* *}$ & $-0.0117^{* * *}$ & 0.00182 & 0.00401 \\
\hline & $(0.00258)$ & $(0.00265)$ & $(0.00265)$ & $(0.00549)$ \\
\hline
\end{tabular}




\begin{tabular}{|c|c|c|c|c|}
\hline \multirow[t]{2}{*}{$\mathrm{RTA}_{\mathrm{ij}}$} & $0.680^{* * *}$ & $0.768^{* * *}$ & $0.599 * * *$ & -0.0758 \\
\hline & $(0.0406)$ & $(0.0437)$ & $(0.0477)$ & $(0.0774)$ \\
\hline \multirow[t]{2}{*}{ RTA $_{\mathrm{ij}} \cdot$ Recession ${ }_{\mathrm{ijt}}$} & -0.0270 & -0.0340 & 0.0696 & -0.115 \\
\hline & $(0.0420)$ & $(0.0467)$ & $(0.0623)$ & $(0.103)$ \\
\hline \multirow[t]{2}{*}{ 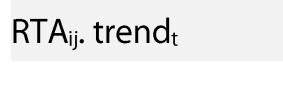 } & $-0.0144^{* * *}$ & $-0.0179 * * *$ & -0.00108 & $0.0199 * * *$ \\
\hline & $(0.00284)$ & $(0.00302)$ & $(0.00329)$ & $(0.00588)$ \\
\hline Observations & 407,320 & 407,320 & 407,320 & 407,320 \\
\hline R-squared & 0.910 & 0.945 & 0.875 & 0.700 \\
\hline
\end{tabular}

Note: This table displays the results of the estimation of equation (6) with, for each of the trade costs variable, an interaction term with a time trend and with a "Recession" dummy that takes the value 1 if both the importer and exporter country are experiencing a recession in year $t$, estimated with PPML performed on a sample of 140 countries between 1995 and 2015. All regressions include the Recession dummy, origin*year and destination*year fixed effects and standard errors are clustered at the country-pair level. CL refers to common language; Contig to Contiguity, Dist to Distance and RTA to Regional Trade Agreement ${ }^{* * *} p<0.01,{ }^{* *} p<0.05,{ }^{*} p<0.1$ 

"Sur quoi la fondera-t-il l'économie du monde qu'il veut gouverner? Sera-ce sur le caprice de chaque particulier? Quelle confusion! Sera-ce sur la justice? Il l'ignore."

Pascal

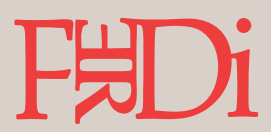

Created in 2003, the Fondation pour les études et recherches sur le développement international aims to promote a fuller understanding of international economic development and the factors that influence it.

\section{$\hookrightarrow$ Contact}

www.ferdi.fr

contact@ferdi.fr

+33 (0)4 73177530 